\title{
Mineralogical and Geochemical Features of Cretaceous Bauxite from San Giovanni Rotondo (Apulia, Southern Italy): A Provenance Tool
}

\author{
Rosa Sinisi $(\mathbb{D}$ \\ Department of Sciences, University of Basilicata, Viale Ateneo Lucano 10, Potenza 85100, Italy; \\ rosa.sinisi@unibas.it; Tel.: +39-971-206181
}

Received: 5 August 2018; Accepted: 1 December 2018; Published: 4 December 2018

\begin{abstract}
In this study, the mineralogical and chemical compositions of bauxite from San Giovanni Rotondo (SGR) on the Gargano Promontory (northern Apulia, Italy) are presented and discussed with the aim of assessing the nature of its source material. Bauxite from the SGR, which is known as the "Montecatini mine", was exploited intensively until the 1970s to recover alumina. As with most of the autochthonous peri-Mediterranean bauxites, the studied deposit is a karst bauxite with a massive, matrix-supported texture and an oolitic structure. Boehmite and hematite are the main mineral phases, and anatase, rutile, and kaolinite are present in lesser amounts along with detrital zircons and monazite grains. Calcite is abundant only in the deposit's lower portion, triggering a significant dilution effect on trace element concentrations. However, with respect to the average crust and chondrite compositions, strong enrichments of trace metals (up to 10X Upper Continental Crust's (UCC)) and rare earth elements (REEs, up to 800X chondrite) exist throughout the studied deposit. The distribution of REEs, the $(\mathrm{La} / \mathrm{Yb})_{\mathrm{N}}$ and $\mathrm{Eu} / \mathrm{Eu}^{*}$ ratios, and an $\mathrm{Eu} / \mathrm{Eu}^{*}$ versus $\mathrm{Sm} / \mathrm{Nd}$ diagram have been used for determining the bauxite's provenance. These geochemical proxies point to a parental material consisting of a mixture of distant magmatic and siliciclastic components.
\end{abstract}

Keywords: karst bauxite; mineralogy; provenance proxy; rare earth elements; southern Italy

\section{Introduction}

Bauxites are residual deposits that are formed as the result of intense weathering of alumosilicate-rich parent rocks, mainly in humid tropical to sub-tropical climates [1]. According to the geological features of bedrock, bauxite deposits can be grouped into two categories: karst bauxite and lateritic bauxite. Karst bauxites include deposits developed on and hosted by carbonate rocks; lateritic bauxites consist of deposits formed on alumosilicate rocks. Regardless of their parent rock, bauxites have great economic significance mainly because of the high concentrations of Al-bearing mineral phases. Moreover, bauxite deposits represent an important potential alternative (re)source of critical metals, including rare earth elements, as was recently stated in the latest European Union report on critical raw materials [2-4].

Worldwide, karst bauxite deposits have been the subject of numerous geological, petrographical, mineralogical, and geochemical investigations aimed at tracing their possible source rocks and revealing the ore-forming process [5-12]. However, the lack of sediment and/or rock representing a bauxite deposit's parental material makes the achievement of these goals more difficult, and commonly different findings are suggested for the same deposit.

In the peri-Mediterranean regions, a number of karst bauxite deposits have occurred, mainly in association with the exhumed carbonate platforms of the Tethys Ocean, which have been affected by intense karstification and weathering during several emersion events that occurred during the Upper Paleozoic era to the Mesozoic era [13]. The southern Italian karst bauxites were formed during 
a late Cretaceous (late Aptian to early Coniacian) hiatus on a Bahamian-type platform that is largely exposed within the southern Apennines [14]. These deposits are located in the Abruzzi Mountains and in the Apulia (the Gargano Peninsula and the Murge district) and Campania (the Matese and Caserta Mountains) regions.

Several paleogeographic scenarios, including those based on elemental proxies as well as on zircon ages, have been proposed to explain the provenance of karst bauxites in southern Italy [15,16]. Recently, [3] stated that during the Cretaceous period, the Apulia Carbonate Platform (ACP) was part of a larger carbonate platform, the Adria platform, that was linked to a continental margin of the southern Tethys. Such a continental margin (likely belonging to the North Africa craton) was repeatedly affected by sea level fluctuations that produced the emersion of the platform and the consequent formation of autochthonous and allochthonous bauxite deposits. However, uncertainties remain regarding the relationship between the Adria and African plates because a different paleogeographic model exists as an alternative realm of the Cretaceous-period Tethys. In this model proposed by Stampfli, et al. [17], Adria is considered to be an independent microplate that is separated from the African plate by a Neo-Tethys oceanic domain. Therefore, to better constrain the paleotectonic setting of the western Mediterranean, additional information is needed, and, in this sense, the study of the Apulian bauxites could provide useful information.

The present paper focuses on the most representative bauxite deposit of the Gargano Peninsula (northern Apulia), which is located at the San Giovanni Rotondo site, for which only few data are actually available in the literature. The main aim of the paper is to furnish new data on, and a more detailed description of, the mineralogy and geochemistry of the bauxite from San Giovanni Rotondo, while paying particular attention to the distribution of conservative elements suitable for provenance studies and paleogeographical reconstructions. Rare earth elements and some elemental ratios, namely $\mathrm{Eu} / \mathrm{Eu}^{*}$ and $(\mathrm{La} / \mathrm{Yb})_{\mathrm{N}}$, have been particularly useful for the purpose of providing suggestions on the possible source material of the studied bauxite, and, consequently, on the paleogeography of the examined area.

\section{Geological Framework}

The studied area is located on the Gargano Promontory, which is the northern portion of the exposed Apulian Carbonate Platform (ACP, Central Mediterranean) that, during the Mesozoic era, represented one of the paleogeographic elements of the southernmost Tethys (Figure 1a). The formation and evolution of the ACP occurred during the Triassic to early Cretaceous period [18], when the Apulian platform acted as a passive continental margin. Its tectonic evolution was controlled mainly by the convergence of the African and Eurasian cratons, in the middle-late Cretaceous period, during the early phases of the Alpine Orogeny [19]. At present, the Apulian platform is part of the stable and relatively undeformed foreland of the Apennine thrust and fold belt. It is tectonically divided into three main structural blocks, namely the Gargano Promontory, the Murge area, and the Salento Peninsula [20], by the NW-SE-trending Apenninic fault and the NE- SW-trending anti-Apenninic fault (Figure 1b). 

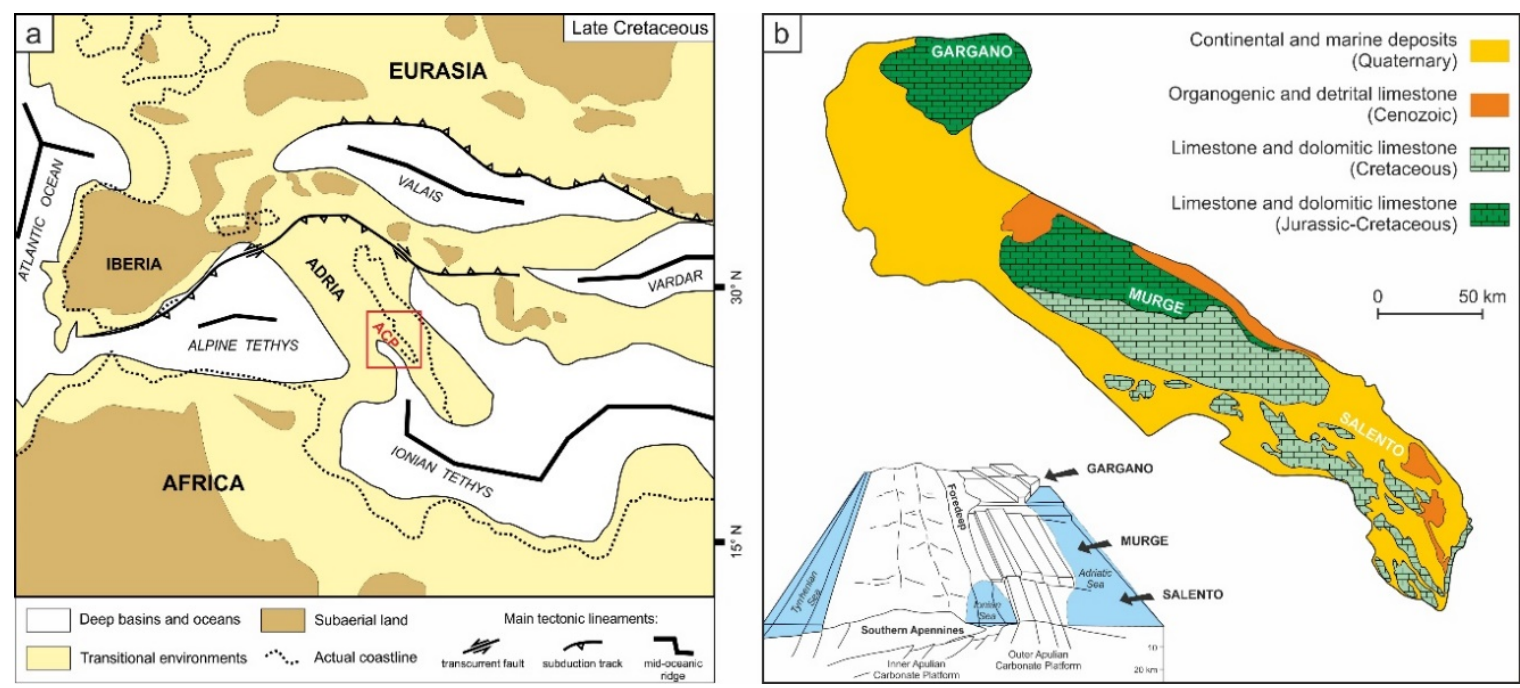

Figure 1. (a) Paleogeographic sketch of the Mediterranean area during the Late Cretaceous period (Modified from Ricchetti, et al. [18]). The red box shows the location of the Apulia Carbonate Platform (ACP) microplate. (b) Simplified geological map of Apulia and the position of the Gargano, Murge, and Salento tectonic blocks.

The Gargano Promontory is the only region of the ACP in which Late Jurassic-middle Eocene carbonates of platform-to-basin transition are exposed: shallow-water Apulia Platform carbonate rocks in the promontory's western portion; and slope and basin deposits in its eastern portion. Specifically, the promontory consists of a buried 3000-3500-m-thick sequence of Jurassic and Cretaceous shallow-water carbonates that are covered by Upper Jurassic to Eocene carbonates representing platform-to-basin settings [21], and, with a minor extension, by Miocene carbonates and siliciclastic sediments [22] (Figure 2a). In the Gargano district, similarly to the Murge area and the Salento Peninsula, regional intra-Cretaceous unconformities locally occur in the ACP rocks, providing evidence of a wide depositional hiatus and long-lasting subaerial exposure to events that resulted in widespread karstification and bauxite formation. According to Esu and Girotti [23] and Mongelli, et al. [24], the autochthonous bauxite deposits of the Murge and Gargano districts were formed during Late Cretaceous (Cenomanian-Turonian) exposure events, while the reworked allochthonous Salento-type bauxite was deposited during the Campanian period.

The bauxite from Gargano consists of the sedimentary infill of both canyon-like cavities and irregular 3-10-m-thick lenses lying between the karstified San Giovanni Rotondo limestone (Valanginian-Aptian) [25] at the bottom, and the transgressive Altamura limestone (ConiacianSantonian) [26] at the top [27,28] (Figure 2b). At the San Giovanni Rotondo site, the bauxite under study is part of an underground mine (usually named the "Montecatini mine"), which was exploited intensively until the 1970s. According to Mongelli, [29], the deposit is a typical Mediterranean-type karst bauxite (sensu [5]) deriving from in situ bauxitization of primitive clays and the late formation of pedogenetic iron-rich concretions. 

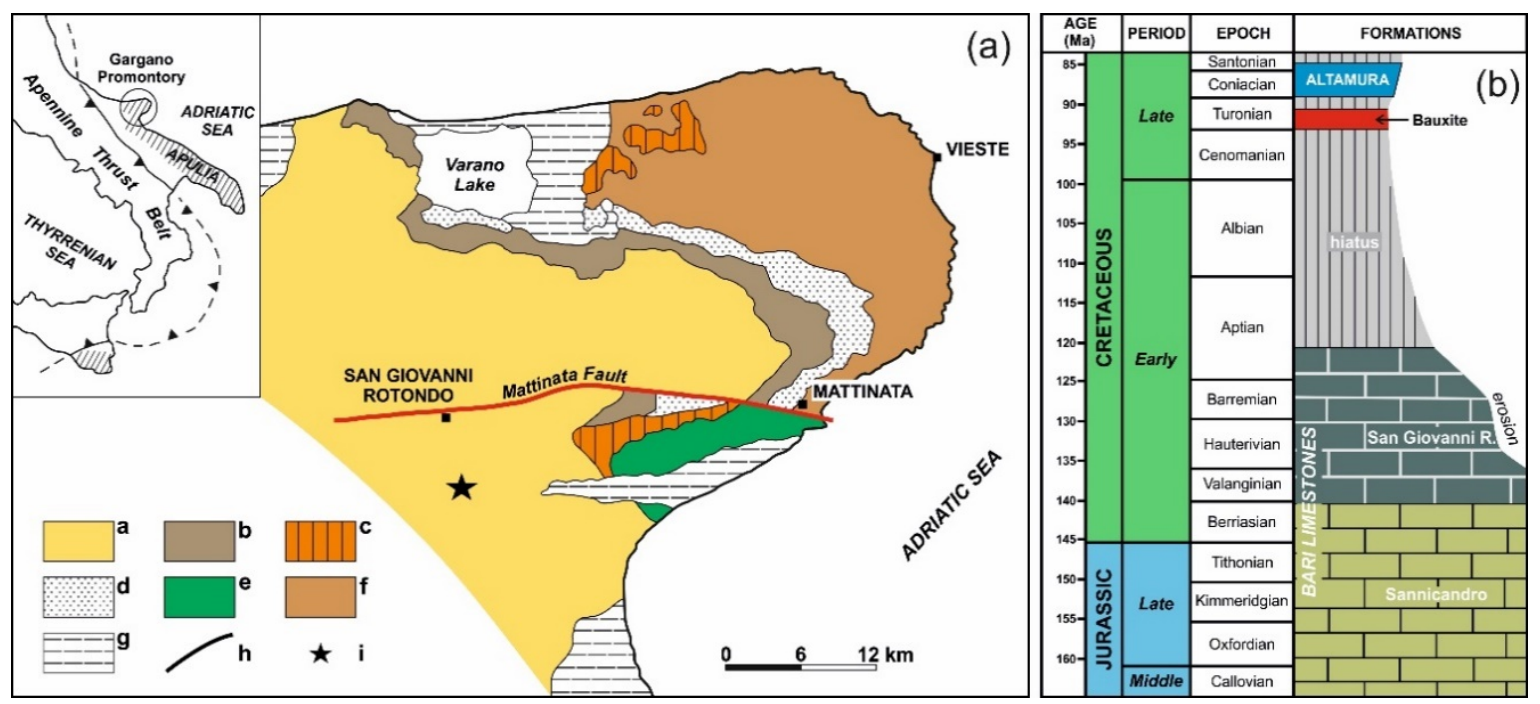

Figure 2. (a) Geological map showing the Cretaceous units that outcrop the Gargano Promontory. a:shallow-water facies associations (Malm-Cenomanian), b: marginal facies associations (Malm- Lower Cretaceous), c: slope and related marginal facies associations (Cenomanian), d: slope facies associations (Tithonian-Albian); e: slope facies associations (Turonian-Senonian), $\mathrm{f}$ : basinal facies associations (Berriasian-Senonian p.p.), g: continental clastics (Quaternary), h: Mattinata transcurrent fault, and i: sampled bauxite. (b) A representative stratigraphic column (Modified from [30]) of the sampling site that shows the carbonate rocks at the bottom and the top of the San Giovanni Rotondo (SGR) bauxite deposit.

\section{Sampling and Analytical Procedures}

Fifteen samples of bauxite ore from the San Giovanni Rotondo (hereafter SGR) deposit were collected from (up to $-11 \mathrm{~m}$ of depth) the disused, underground Montecatini mine (Figure 2). Eight samples (SGR1 to SGR10) are representative of the upper portion of the deposit, which is mainly composed of brownish-reddish sediments with millimetre-sized ooidal concretions widespread in a clay-grained matrix. Seven samples (SGR11 to SGR20) are from the lower portion of the deposit, which consists of dark-red, massive sediments in which millimeter to centimeter-sized ooids are dispersed in a very fine matrix of clays and carbonates.

Different types of analysis were performed on the bulk rock samples in order to characterize the SGR bauxite from a mineralogical, textural, and chemical point of view. The mineralogical composition was identified by X-ray diffraction (XRD) analysis of randomly oriented samples, previously powdered by hand in an agate jar, using a Siemens (Munich, Germany) D5000 diffractometer equipped with a $\mathrm{Cu}$ tube and a graphite monochromator. The XRD analysis was performed from $5^{\circ}$ to $70^{\circ} 2 \theta$ with $0.01^{\circ} 2 \theta$ /step and a $2 \mathrm{~s}$ counting time. The textural and microchemical features were studied by scanning electron microscopy (SEM) using a XL30 Philips LaB6 ESEM equipped with an energy dispersive X-ray spectrometer (EDS) (FEI, Munich, Germany) at the Department of Sciences, University of Basilicata (Italy). Concentrations of major and trace elements (including rare earth elements, REE) were determined by inductively coupled plasma-mass spectroscopy (ICP-MS) at Activation Laboratories Ltd., Canada. Analytical uncertainties were less than $\pm 5 \%$, except for elements at a concentration of $10 \mathrm{ppm}$ or lower, for which uncertainties were $\pm 5 \%$ to $\pm 10 \%$. Total loss on ignition (LOI) was determined gravimetrically after heating overnight at $950{ }^{\circ} \mathrm{C}$.

For the purpose of discussion, the REE concentrations were normalized to a Chondrite standard [31]. The $\mathrm{Ce}$ and $\mathrm{Eu}$ anomalies were calculated as $\mathrm{Ce} / \mathrm{Ce}^{*}=\mathrm{Ce}_{\mathrm{N}} / \sqrt{ }\left(\mathrm{La}_{\mathrm{N}}{ }^{*} \operatorname{Pr}_{\mathrm{N}}\right)$ and $\mathrm{Eu} / \mathrm{Eu}^{*}=\mathrm{Eu}_{\mathrm{N}} / \sqrt{ }\left(\mathrm{Sm}_{\mathrm{N}}{ }^{*} \mathrm{Gd} \mathrm{d}_{\mathrm{N}}\right)$, respectively [32], where the subscript " $\mathrm{N}^{\prime \prime}$ refers to normalized values for chondrite. 


\section{Results}

\subsection{Mineralogical Composition and Textural Features}

The XRPD patterns representative of the upper (SGR8) and lower (SGR13) portions of the SGR deposit are displayed in Figure 3. These show that, throughout the deposit, boehmite $(\gamma-\mathrm{AlO}(\mathrm{OH}))$ and hematite $\left(\alpha-\mathrm{Fe}_{2} \mathrm{O}_{3}\right)$ are the principal mineral phases, and that Ti oxides (mainly anatase and scarce rutile, $\left.\mathrm{TiO}_{2}\right)$ and kaolinite $\left(\mathrm{Al}_{2} \mathrm{Si}_{2} \mathrm{O}_{5}(\mathrm{OH})_{4}\right)$ are accessory phases. In addition to these minerals, calcite $\left(\mathrm{CaCO}_{3}\right)$ was detected in two samples from the upper part of the deposit (SGR5 and SGR10), and in all samples from its lower part.

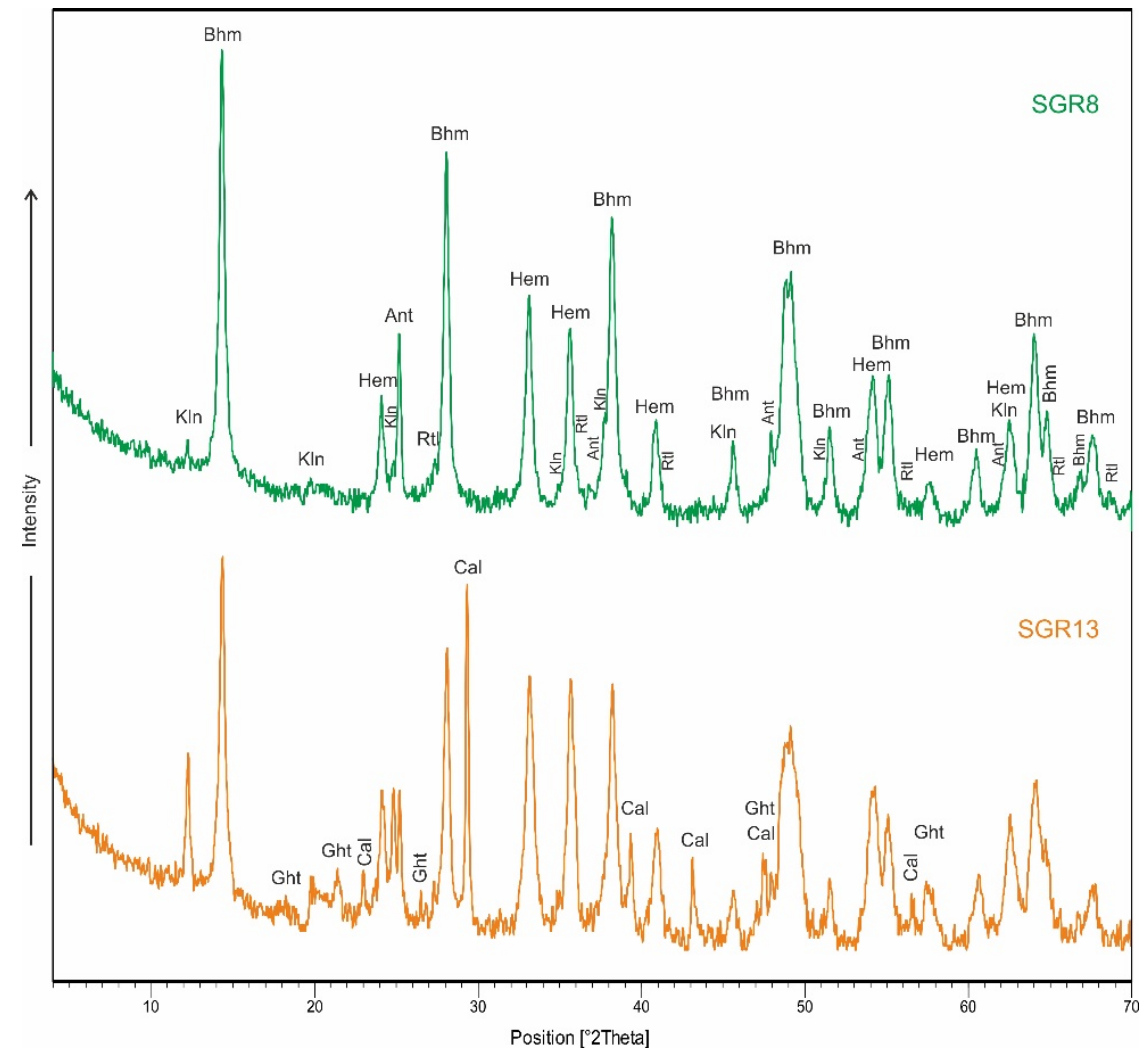

Figure 3. XRPD results of two SGR samples representative of the upper and lower portions of the deposit. Ant = anatase, $\mathrm{Bhm}=$ boehmite, $\mathrm{Cal}=$ calcite, $\mathrm{Ght}=$ goethite, Hem = hematite, $\mathrm{Kln}=$ kaolinite, Rtl = rutile.

ESEM observations and the SEM-EDS analysis showed that the SGR bauxite is characterized by a matrix-supported texture with an oolitic structure similar to that described by previous authors for the other Apulia autochthonous bauxites (e.g., bauxite from the Murge) [16,29,33,34]. The ooidal concretions, which are embedded in a pelitomorphic matrix (Figure 4a), have variable sizes (50-500 $\mu \mathrm{m})$ and concentric structures that are formed by the alternation of Al-hematitic and boehmitic shells that surround a central nucleus composed of authigenic boehmite (Figure $4 \mathrm{~b}$ ) and authigenic hematite (Figure 4c). The matrix containing the concretions usually consists of boehmite, although hematite, kaolinite, and anatase are common in it. Detrital zircon (general formula $\mathrm{ZrSiO}_{4}$ ) and monazite (general formula $\mathrm{CePO}_{4}$ ) grains, usually $10-20 \mu \mathrm{m}$ in size (Figure $4 \mathrm{~d}, \mathrm{e}$ ), are present in ooids and the matrix as well. All of the analyzed monazites contain significant amounts of $\mathrm{Nd}$ and $\mathrm{La}$, in addition to Ce, as documented by the EDS microanalysis results shown in Figure $4 \mathrm{f}$.

$\mathrm{Al}$ and Fe mineral phases only appear in the samples from the lower part of the SGR deposit; locally, the matrix is made up of calcite, which replaces the $\mathrm{Al}$ and Fe mineral phases. 

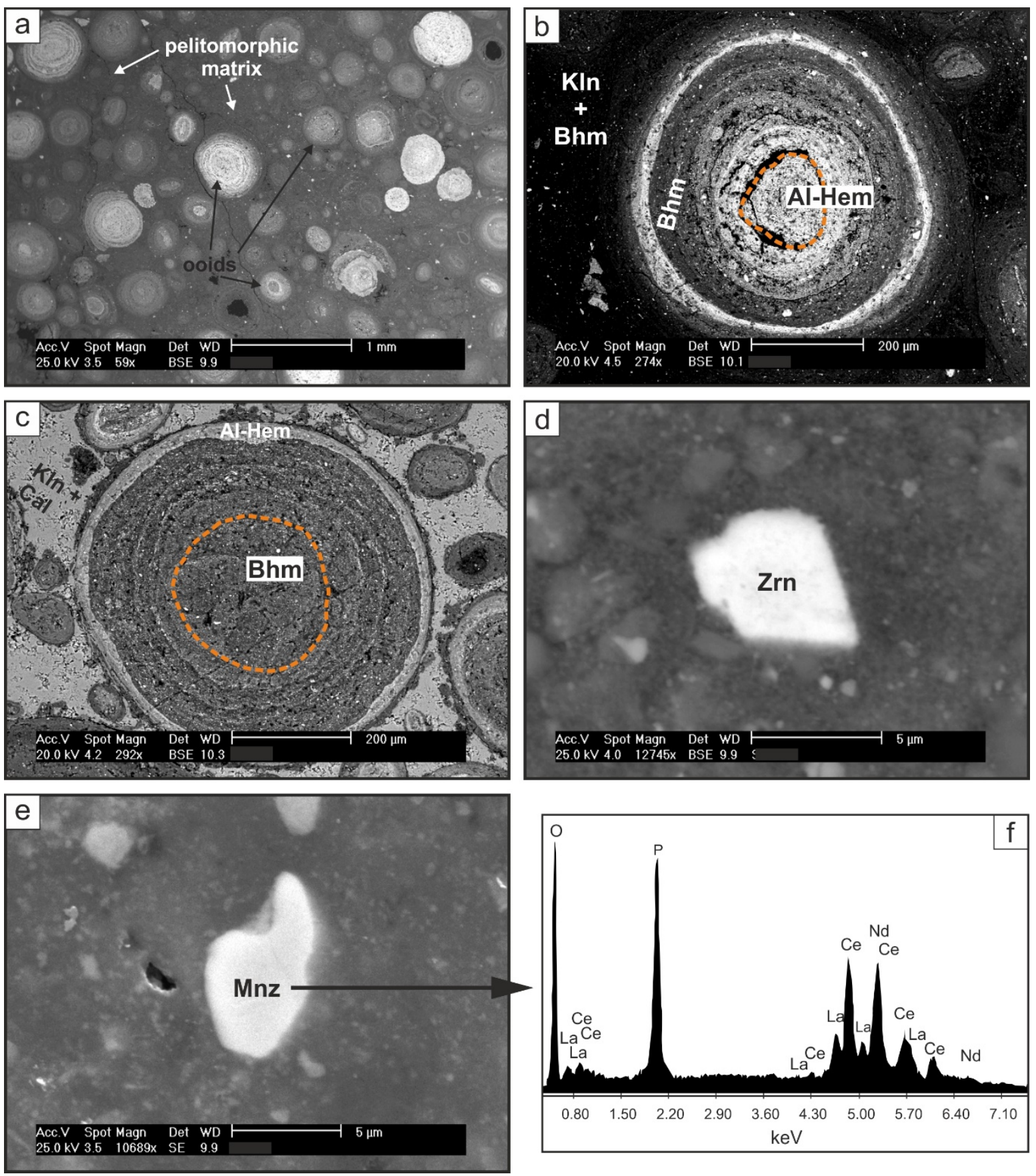

Figure 4. SEM images showing the principal microscopic features of the SGR bauxite. (a) ooidal texture formed by a pelitomorphic matrix and variable-sized spherical concretions, (b) an ooid with an authigenic hematite nucleus (highlighted by the orange dashed line), (c) an ooid with an authigenic boemite nucleus (within the orange dashed line), (d) detrital zircon and (e) monazite embedded in the matrix, (f) EDS results for the monazite shown in (e). Al-Hem = Al-hematite, Bhm = boehmite, $\mathrm{Cal}=$ calcite, $\mathrm{Kln}=$ kaolinite, $\mathrm{Mnz}=$ monazite, $\mathrm{Zrn}=$ zircon .

\subsection{Geochemistry}

Table 1 shows the chemical compositions and elemental ratios of the examined bauxite samples. 
Table 1. Chemical composition of the San Giovanni Rotondo (SGR) bauxite.

\begin{tabular}{|c|c|c|c|c|c|c|c|c|c|c|c|c|c|c|c|}
\hline Elements & SGR 1 & SGR 3 & SGR 4 & SGR 5 & SGR 6 & SGR 7 & SGR 9 & SGR 10 & SGR 11 & SGR 12 & SGR 13 & SGR 15 & SGR 17 & SGR 19 & SGR 20 \\
\hline \multicolumn{16}{|c|}{ Major Elements (wt.\%) } \\
\hline $\mathrm{SiO}_{2}$ & 2.1 & 2.04 & 1.94 & 3.83 & 2.21 & 1.15 & 1.06 & 2.58 & 2.82 & 3.42 & 4.58 & 3.76 & 4.46 & 4.05 & 3.61 \\
\hline $\mathrm{Al}_{2} \mathrm{O}_{3}$ & 56.85 & 56.25 & 57.39 & 52.04 & 56.1 & 54.75 & 55.67 & 51.51 & 38.71 & 44.69 & 41.29 & 40.33 & 27.51 & 38.86 & 36.23 \\
\hline $\mathrm{Fe}_{2} \mathrm{O}_{3}(\mathrm{~T})$ & 21.08 & 21.47 & 19.81 & 18.07 & 21.29 & 24.52 & 23.66 & 21.13 & 12.27 & 15.75 & 15.1 & 20.65 & 11.91 & 15.41 & 20.3 \\
\hline MnO & 0.124 & 0.123 & 0.126 & 0.108 & 0.135 & 0.165 & 0.163 & 0.144 & 0.073 & 0.075 & 0.064 & 0.086 & 0.102 & 0.087 & 0.104 \\
\hline $\mathrm{MgO}$ & 0.11 & 0.11 & 0.08 & 0.12 & 0.09 & 0.06 & 0.06 & 0.11 & 0.2 & 0.16 & 0.18 & 0.16 & 0.23 & 0.18 & 0.17 \\
\hline $\mathrm{CaO}$ & 0.32 & 0.32 & 0.27 & 4.34 & 0.36 & 0.18 & 0.14 & 4.25 & 18.84 & 11.81 & 14.44 & 13.1 & 25.81 & 15.91 & 14.75 \\
\hline $\mathrm{Na}_{2} \mathrm{O}$ & 0.08 & 0.08 & 0.07 & 0.06 & 0.1 & 0.03 & 0.02 & 0.02 & 0.01 & 0.01 & 0.04 & 0.02 & 0.02 & 0.02 & 0.02 \\
\hline $\mathrm{K}_{2} \mathrm{O}$ & 0.04 & 0.04 & 0.03 & 0.06 & 0.05 & 0.01 & 0.005 & 0.03 & 0.03 & 0.03 & 0.05 & 0.03 & 0.05 & 0.04 & 0.04 \\
\hline $\mathrm{TiO}_{2}$ & 5.286 & 5.196 & 5.267 & 4.168 & 5.033 & 5.403 & 5.449 & 4.519 & 2.49 & 2.787 & 2.598 & 2.456 & 1.81 & 2.422 & 2.387 \\
\hline $\mathrm{P}_{2} \mathrm{O}_{5}$ & 0.09 & 0.06 & 0.06 & 0.06 & 0.07 & 0.07 & 0.08 & 0.06 & 0.04 & 0.07 & 0.05 & 0.07 & 0.03 & 0.05 & 0.06 \\
\hline LOI & 13.59 & 13.39 & 13.5 & 15.75 & 13.79 & 12.5 & 12.46 & 14.58 & 23.06 & 20.39 & 20.21 & 19.32 & 26.91 & 21.8 & 20.99 \\
\hline Total & 99.67 & 99.08 & 98.56 & 98.6 & 99.22 & 98.84 & 98.76 & 98.92 & 98.55 & 99.2 & 98.61 & 99.97 & 98.84 & 98.83 & 98.65 \\
\hline \multicolumn{16}{|c|}{ Trace Elements (ppm) } \\
\hline Sc & 68 & 67 & 65 & 61 & 73 & 68 & 65 & 62 & 43 & 47 & 45 & 55 & 35.00 & 47 & 51 \\
\hline V & 382 & 390 & 384 & 323 & 401 & 499 & 485 & 405 & 232 & 301 & 284 & 331 & 193 & 260 & 332 \\
\hline Ba & 39 & 30 & 39 & 28 & 43 & 41 & 29 & 28 & 21 & 25 & 48 & 20 & 33 & 24 & 23 \\
\hline $\mathrm{Sr}$ & 39 & 18 & 17 & 22 & 17 & 15 & 14 & 21 & 29 & 21 & 52 & 26 & 61 & 30 & 32 \\
\hline $\mathbf{Y}$ & 46 & 46 & 45 & 55 & 47 & 35 & 35 & 47 & 54 & 53 & 57 & 52 & 70 & 64 & 63 \\
\hline $\mathrm{Cr}$ & 540 & 580 & 540 & 420 & 510 & 650 & 630 & 500 & 350 & 420 & 370 & 400 & 320 & 360 & 440 \\
\hline Co & 26 & 26 & 27 & 24 & 30 & 32 & 31 & 49 & 17 & 19 & 17 & 21 & 12 & 17 & 20 \\
\hline $\mathrm{Ni}$ & 200 & 200 & 210 & 190 & 210 & 230 & 240 & 240 & 170 & 200 & 180 & 180 & 150 & 180 & 180 \\
\hline Ga & 69 & 69 & 70 & 61 & 68 & 68 & 68 & 61 & 43 & 53 & 45 & 47 & 31 & 44 & 46 \\
\hline $\mathrm{Nb}$ & 100 & 96 & 100 & 83 & 102 & 107 & 102 & 97 & 61 & 73 & 67 & 68 & 46 & 61 & 64 \\
\hline La & 93.8 & 103 & 85.3 & 104 & 92.5 & 85.6 & 81.7 & 94.8 & 73.5 & 96.9 & 90.5 & 102 & 97.6 & 109 & 117 \\
\hline \multicolumn{16}{|c|}{ Rare Earth Elements (ppm) } \\
\hline $\mathrm{Ce}$ & 232 & 239 & 405 & 333 & 276 & 634 & 556 & 353 & 210 & 351 & 225 & 273 & 259 & 295 & 296 \\
\hline Pr & 23.3 & 26.3 & 20.7 & 27.2 & 22.3 & 18.1 & 17 & 21.5 & 19.8 & 25.8 & 23.1 & 25.8 & 25 & 29.2 & 30 \\
\hline $\mathrm{Nd}$ & 85.8 & 96.8 & 74.3 & 102 & 82.1 & 61.2 & 58.3 & 77 & 74.2 & 92.8 & 84.6 & 96.2 & 92.8 & 108 & 111 \\
\hline Sm & 17.2 & 19 & 14.8 & 20.2 & 16.8 & 12.1 & 11.4 & 14.9 & 15.7 & 19.7 & 17.2 & 19.3 & 19.4 & 22.4 & 22.4 \\
\hline Eu & 4.08 & 4.56 & 3.52 & 4.91 & 3.99 & 2.83 & 2.63 & 3.58 & 3.87 & 4.57 & 4.12 & 4.58 & 4.8 & 5.24 & 5.39 \\
\hline Gd & 12.8 & 14.2 & 11.7 & 16.9 & 13.1 & 9 & 8.9 & 12.2 & 13.4 & 15.7 & 14.4 & 16 & 17.1 & 18.2 & 19.1 \\
\hline $\mathbf{T b}$ & 2.1 & 2.4 & 2 & 2.5 & 2.2 & 1.6 & 1.5 & 1.9 & 2.1 & 2.3 & 2.2 & 2.4 & 2.5 & 2.7 & 2.8 \\
\hline
\end{tabular}


Table 1. Cont.

\begin{tabular}{|c|c|c|c|c|c|c|c|c|c|c|c|c|c|c|c|}
\hline Elements & SGR 1 & SGR 3 & SGR 4 & SGR 5 & SGR 6 & SGR 7 & SGR 9 & SGR 10 & SGR 11 & SGR 12 & SGR 13 & SGR 15 & SGR 17 & SGR 19 & SGR 20 \\
\hline \multicolumn{16}{|c|}{ Rare Earth Elements (ppm) } \\
\hline Dy & 12.9 & 13.8 & 11.7 & 14.6 & 13.1 & 9.5 & 9.2 & 10.9 & 12.1 & 13.6 & 12.5 & 13.5 & 14 & 14.4 & 15.6 \\
\hline Ho & 2.4 & 2.6 & 2.3 & 2.7 & 2.5 & 1.9 & 1.8 & 2.1 & 2.3 & 2.5 & 2.3 & 2.5 & 2.6 & 2.7 & 2.9 \\
\hline Er & 7.3 & 7.7 & 6.9 & 7.8 & 7.6 & 5.6 & 5.5 & 6 & 6.7 & 7.2 & 6.6 & 7 & 7 & 7.6 & 8.1 \\
\hline $\mathrm{Tm}$ & 1.11 & 1.15 & 1.07 & 1.17 & 1.13 & 0.88 & 0.85 & 0.92 & 0.98 & 1.06 & 0.95 & 1.05 & 1.01 & 1.09 & 1.17 \\
\hline $\mathbf{Y b}$ & 8 & 8.3 & 7.3 & 7.8 & 8.1 & 6 & 5.8 & 6.1 & 6.5 & 7.2 & 6.4 & 6.5 & 6.2 & 7.2 & 7.3 \\
\hline Lu & 1.18 & 1.26 & 1.11 & 1.13 & 1.23 & 0.92 & 0.9 & 0.87 & 0.97 & 1.09 & 0.95 & 0.97 & 0.9 & 1.05 & 1.15 \\
\hline ¿REEs & 504 & 540.07 & 647.7 & 645.9 & 542.7 & 849.2 & 761.5 & 605.77 & 442.12 & 641.42 & 490.82 & 570.8 & 549.91 & 623.78 & 639.91 \\
\hline $\mathrm{Ce} / \mathrm{Ce}^{*}$ & 1.16 & 1.08 & 2.26 & 1.47 & 1.42 & 3.77 & 3.50 & 1.83 & 1.29 & 1.64 & 1.15 & 1.25 & 1.23 & 1.23 & 1.17 \\
\hline $\mathrm{Eu} / \mathrm{Eu}^{*}$ & 0.84 & 0.85 & 0.82 & 0.81 & 0.82 & 0.83 & 0.80 & 0.81 & 0.82 & 0.79 & 0.80 & 0.80 & 0.81 & 0.79 & 0.80 \\
\hline$(\mathrm{La} / \mathrm{Yb})_{\mathrm{N}}$ & 7.92 & 8.39 & 7.90 & 9.01 & 7.72 & 9.64 & 9.52 & 10.50 & 7.64 & 9.09 & 9.56 & 10.60 & 10.64 & 10.23 & 10.83 \\
\hline
\end{tabular}


$\mathrm{Al}_{2} \mathrm{O}_{3}$ (51.51-57.39 wt.\%) and $\mathrm{Fe}_{2} \mathrm{O}_{3}(18.07-24.52$ wt.\%) are the main oxides of the upper portion of the deposit; $\mathrm{Al}_{2} \mathrm{O}_{3}$ (36.23-44.69 wt.\%), $\mathrm{Fe}_{2} \mathrm{O}_{3}$ (12.27-20.65 wt.\%), and $\mathrm{CaO}(11.81-25.81$ wt.\%) are the main oxides of its lower part. Scarce contents of $\mathrm{SiO}_{2}$ and $\mathrm{TiO}_{2}$, ranging between 1.06 and $4.58 \mathrm{wt} . \%$ and between 1.81 and $5.45 \mathrm{wt} . \%$, respectively, are also present across the analyzed bauxite. The other major elemental oxides $\left(\mathrm{MnO}, \mathrm{MgO}, \mathrm{Na}_{2} \mathrm{O}, \mathrm{K}_{2} \mathrm{O}\right.$, and $\mathrm{P}_{2} \mathrm{O}_{5}$ ) have concentrations that are systematically below $1 \mathrm{wt} . \%$.

According to the bauxite classification of Bárdossy, [5], the SGR deposit mainly consists of an Fe-rich bauxite, as suggested by the sample distribution in the $\mathrm{Al}_{2} \mathrm{O}_{3}-\mathrm{SiO}_{2}-\mathrm{Fe}_{2} \mathrm{O}_{3}$ ternary diagram shown in Figure 5.

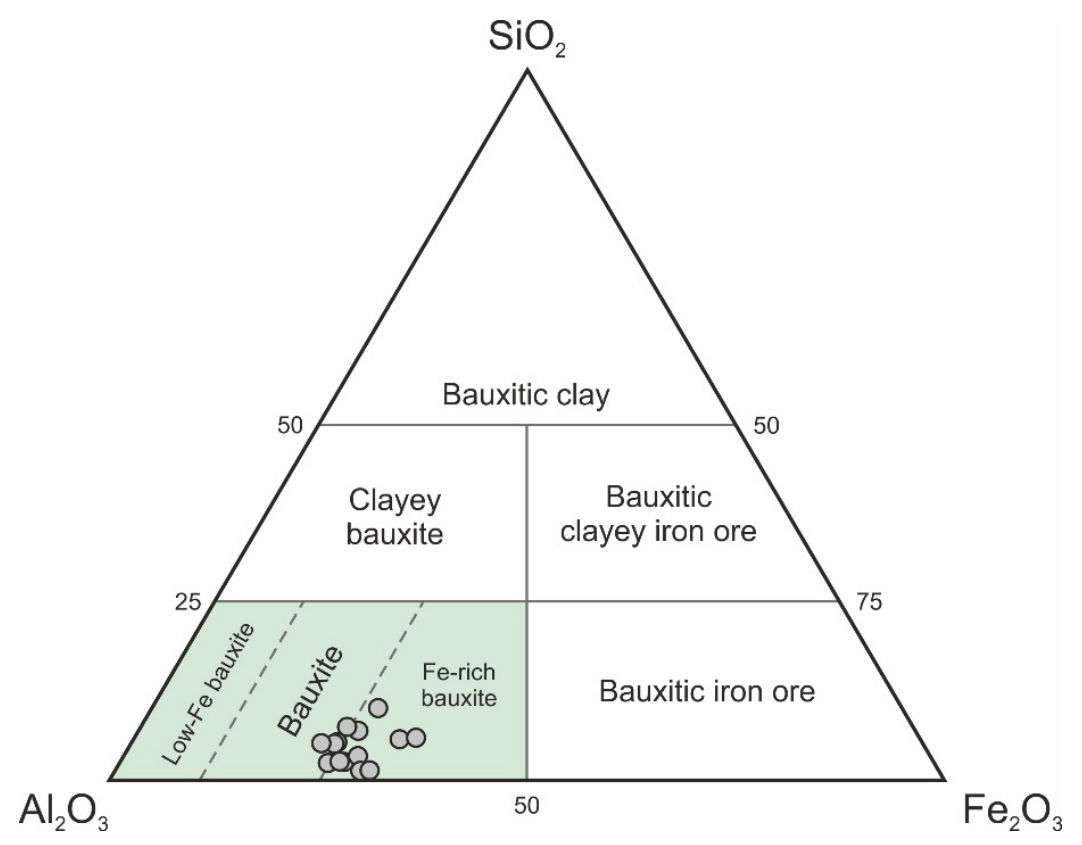

Figure 5. $\mathrm{Al}_{2} \mathrm{O}_{3}-\mathrm{SiO}_{2}-\mathrm{Fe}_{2} \mathrm{O}_{3}$ classification diagram (Modified from Bárdossy, [5]) for the SGR deposit. Grey circles are samples from the studied bauxite.

Binary plots among the major elemental oxides (Figure 6) indicate that, in the studied deposit, positive correlations exist between $\mathrm{Al}_{2} \mathrm{O}_{3}$ and $\mathrm{TiO}_{2}$, and between $\mathrm{Al}_{2} \mathrm{O}_{3}$ and $\mathrm{Fe}_{2} \mathrm{O}_{3}$, whereas negative correlations exist between $\mathrm{Al}_{2} \mathrm{O}_{3}$ and $\mathrm{SiO}_{2}$ and $\mathrm{Al}_{2} \mathrm{O}_{3}$ and $\mathrm{CaO}$. These correlations are typical of strongly weathered deposits where immobile elements accumulate and mobile elements are leached out [35]. This is also confirmed by the low contents of alkali and alkali earth elements, which are highly mobile during chemical weathering [36,37]. 
- Upper deposit

○ Lower deposit
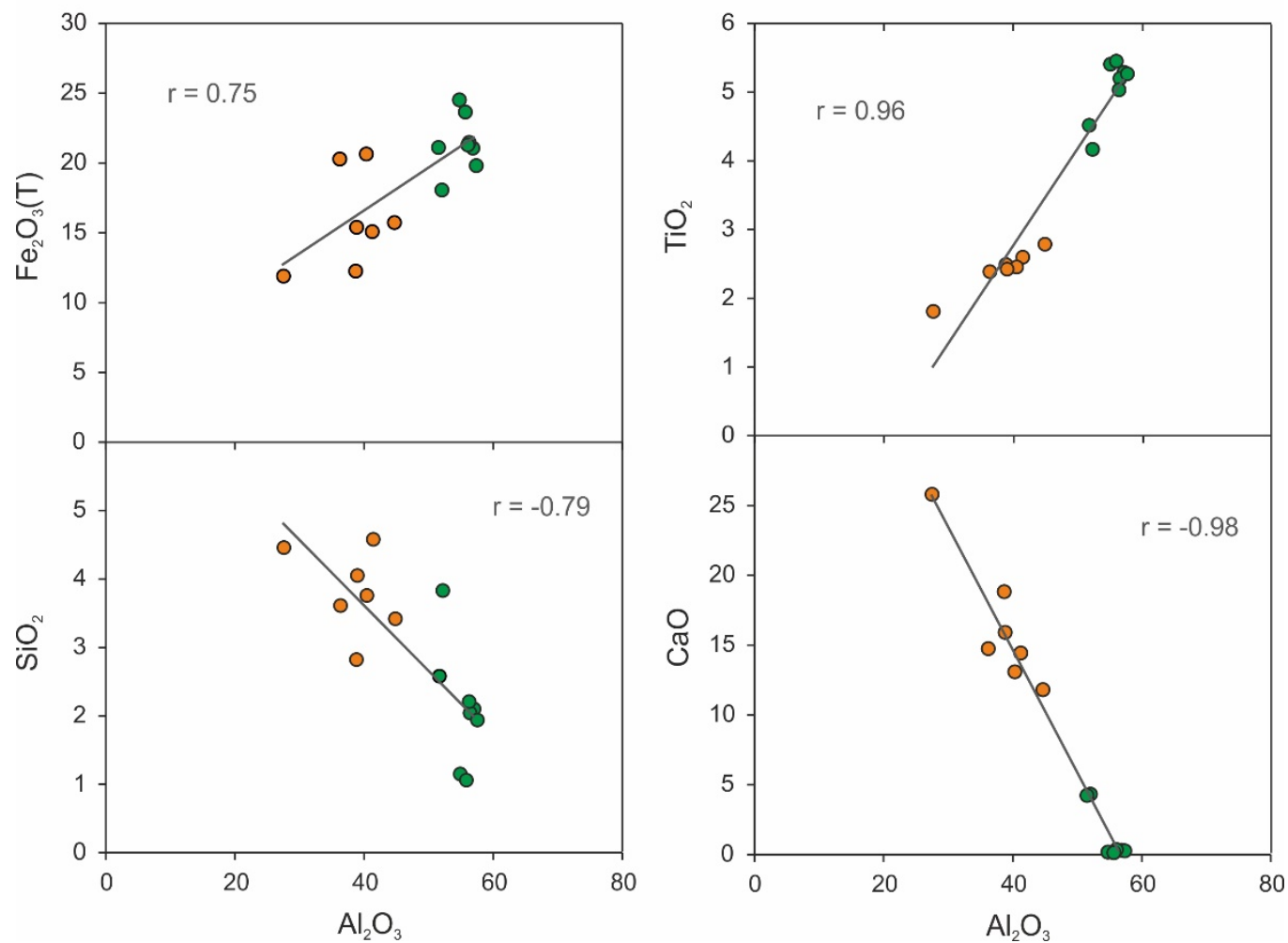

Figure 6. Plots of $\mathrm{Al}_{2} \mathrm{O}_{3}$ versus $\mathrm{Fe}_{2} \mathrm{O}_{3}, \mathrm{SiO}_{2}, \mathrm{TiO}_{2}$, and $\mathrm{CaO}$ with the correlation coefficient (r). See text for further details.

Highly positive correlations of $\mathrm{Al}_{2} \mathrm{O}_{3}$ and $\mathrm{Fe}_{2} \mathrm{O}_{3}$ with $\mathrm{V}\left(\mathrm{r}_{\mathrm{Al} 2 \mathrm{O} 3-\mathrm{V}}=0.82, \mathrm{r}_{\mathrm{Fe} 2 \mathrm{O}-\mathrm{V}}=0.95\right)$, $\mathrm{Ni}\left(\mathrm{r}_{\mathrm{Al} 2 \mathrm{O} 3-\mathrm{Ni}}=0.80, \mathrm{r}_{\mathrm{Fe} 2 \mathrm{O} 3-\mathrm{Ni}}=0.79\right), \mathrm{Cr}\left(\mathrm{r}_{\mathrm{Al} 2 \mathrm{O} 3-\mathrm{Cr}}=0.84, \mathrm{r}_{\mathrm{Fe} 2 \mathrm{O} 3-\mathrm{Cr}}=0.89\right), \mathrm{Sc}\left(\mathrm{r}_{\mathrm{Al} 2 \mathrm{O} 3-\mathrm{Sc}}=0.93\right.$, $\left.\mathrm{r}_{\mathrm{Fe} 2 \mathrm{O} 3-\mathrm{Sc}}=0.88\right), \mathrm{Ga}\left(\mathrm{r}_{\mathrm{Al} 2 \mathrm{O} 3-\mathrm{Ga}}=0.99, \mathrm{r}_{\mathrm{Fe} 2 \mathrm{O} 3-\mathrm{Ga}}=0.80\right), \mathrm{Nb}\left(\mathrm{r}_{\mathrm{Al} 2 \mathrm{O} 3-\mathrm{Nb}}=0.96, \mathrm{r}_{\mathrm{Fe} 2 \mathrm{O} 3-\mathrm{Nb}}=0.84\right)$, and $\mathrm{Co}$ $\left(\mathrm{r}_{\mathrm{Al} 2 \mathrm{O} 3-\mathrm{Co}}=0.69, \mathrm{r}_{\mathrm{Fe} 2 \mathrm{O} 3-\mathrm{Co}}=0.71\right)$ characterize the studied deposit (Figure $7 \mathrm{a}-\mathrm{g}$ ), indicating that $\mathrm{Al}$ and Fe oxides and oxi-hydroxides mineral phases exercise significant control over trace metals. Conversely, $\mathrm{Y}$ and rare earth elements (REEs) are negatively or not correlated with $\mathrm{Al}$ and Fe oxide concentrations (Figure $7 \mathrm{~h}, \mathrm{i}$ ), supporting their preferential inclusion into the detrital minerals (i.e., monazite and zircon) that were detected in the matrix. Moreover, throughout the deposit, only a weak negative correlation was found to exist between REEs and $\mathrm{CaO}$ contents $\left(\mathrm{r}_{\Sigma \mathrm{REEs}-\mathrm{CaO}}=-0.4\right)$, proving that carbonate minerals have a negligible role in the retention of REEs.

The binary plots shown in Figure 7 also highlight a clear subdivision of the trace element concentrations between the upper and lower portions of the analyzed deposit. Specifically, samples from the upper part have higher trace element contents than those from the lower part. This feature, which is associated with the high concentrations of $\mathrm{CaO}$ only in the lower part of the deposit, indicates that a significant dilution effect by carbonate minerals affects the chemistry of the SGR bauxite, resulting in a relative decrease in the trace element contents. The negative correlations between $\mathrm{CaO}$ concentrations and all trace metals $\left(\mathrm{r}_{\mathrm{CaO}-\mathrm{V}}=-0.88, \mathrm{r}_{\mathrm{CaO}-\mathrm{Ni}}=-0.83, \mathrm{r}_{\mathrm{CaO}-\mathrm{Cr}}=-0.88, \mathrm{r}_{\mathrm{CaO}-\mathrm{Sc}}=-0.97, \mathrm{r}_{\mathrm{CaO}-\mathrm{Ga}}=-0.99\right.$, $\mathrm{r}_{\mathrm{CaO}-\mathrm{Nb}}=-0.98$, and $\left.\mathrm{r}_{\mathrm{CaO}-\mathrm{Co}}=-0.72\right)$ support this finding.

A wide range of total rare earth element ( $\Sigma \mathrm{REE})$ concentrations also characterizes SGR bauxite. The $\Sigma$ REE values vary between 442.12 and $849.23 \mathrm{ppm}$, and are inside the typical REEs content range for southern Italy's bauxite deposits $\left(\min _{\Sigma \mathrm{REE}}=56, \max _{\Sigma \mathrm{REE}}=2888\right.$, median $\left._{\Sigma \mathrm{REE}}=446, \mathrm{std}_{\Sigma \mathrm{REE}}=343[4]\right)$. The light REEs (LREEs, La to Sm) and heavy REEs (HREEs, Eu to $\mathrm{Lu}$ ) are moderately fractionated in all samples, causing the $(\mathrm{La} / \mathrm{Yb})_{\mathrm{N}}$ ratio to have high values (7.64-10.83). Moreover, the samples analyzed in this study have uniformly negative Eu anomalies $\left(0.79<\mathrm{Eu} / \mathrm{Eu}^{*}<0.84\right)$, and variable positive $\mathrm{Ce}$ 
anomalies. The Ce/Ce* ratios range between 1.07 and 1.83 in all samples, except for the SGR4 (Ce/Ce* $=2.26)$, SGR7 $\left(\mathrm{Ce} / \mathrm{Ce}^{*}=3.77\right)$, and SGR9 $\left(\mathrm{Ce} / \mathrm{Ce}^{*}=3.49\right)$ samples, which are characterized by higher $\mathrm{Ce} / \mathrm{Ce}^{*}$ values.

$$
\circ \mathrm{Al}_{2} \mathrm{O}_{3} \quad \square \mathrm{Fe}_{2} \mathrm{O}_{3} \quad-\text { Upper deposit }=\text { Lower deposit }
$$
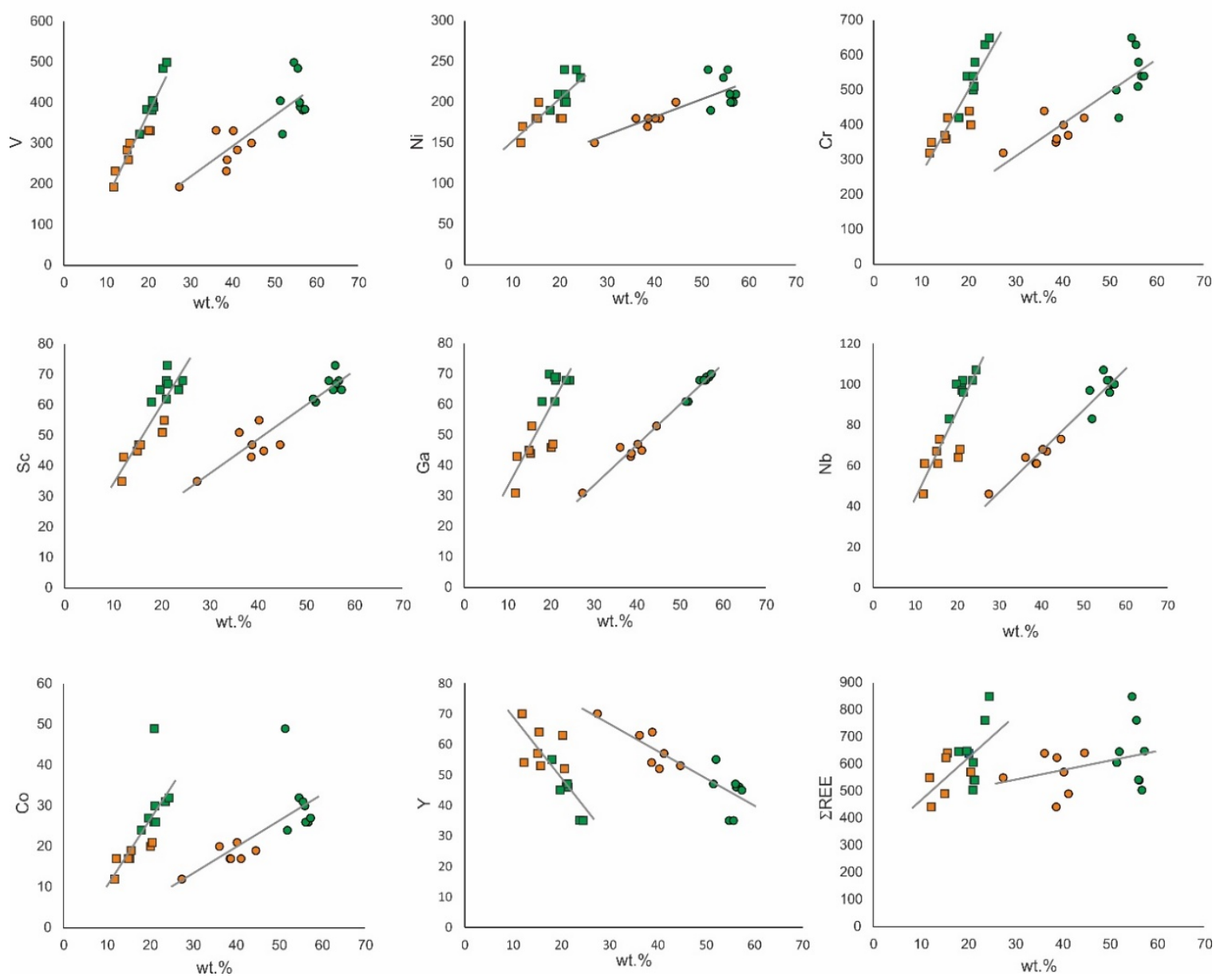

Figure 7. Binary plots showing positive and negative correlations of the $\mathrm{Al}_{2} \mathrm{O}_{3}$ and $\mathrm{Fe}_{2} \mathrm{O}_{3}$ contents (wt.\%) with those of the main trace elements and $\Sigma$ REEs (ppm). See text for further details.

In order to both (a) evaluate the chemical differentiation of the studied ore with respect to the average crustal composition and (b) compare the SGR deposit's chemistry to those of the other Apulian karst bauxites (the Spinazzola and Otranto bauxites), normalization patterns were used. Major and trace element concentrations were normalized to the Upper Continental Crust's (UCC, [38]) composition, and the REEs contents normalized to the Chondrite values [31]. The resulting distribution patterns are displayed in Figure 8.

Regarding the major elements (Figure 8a), the normalization diagrams show analogous paths and concentrations for all the three Apulian deposits. $\mathrm{CaO}$ is the only exception because of its strong variability and high concentration in the SGR bauxite. 

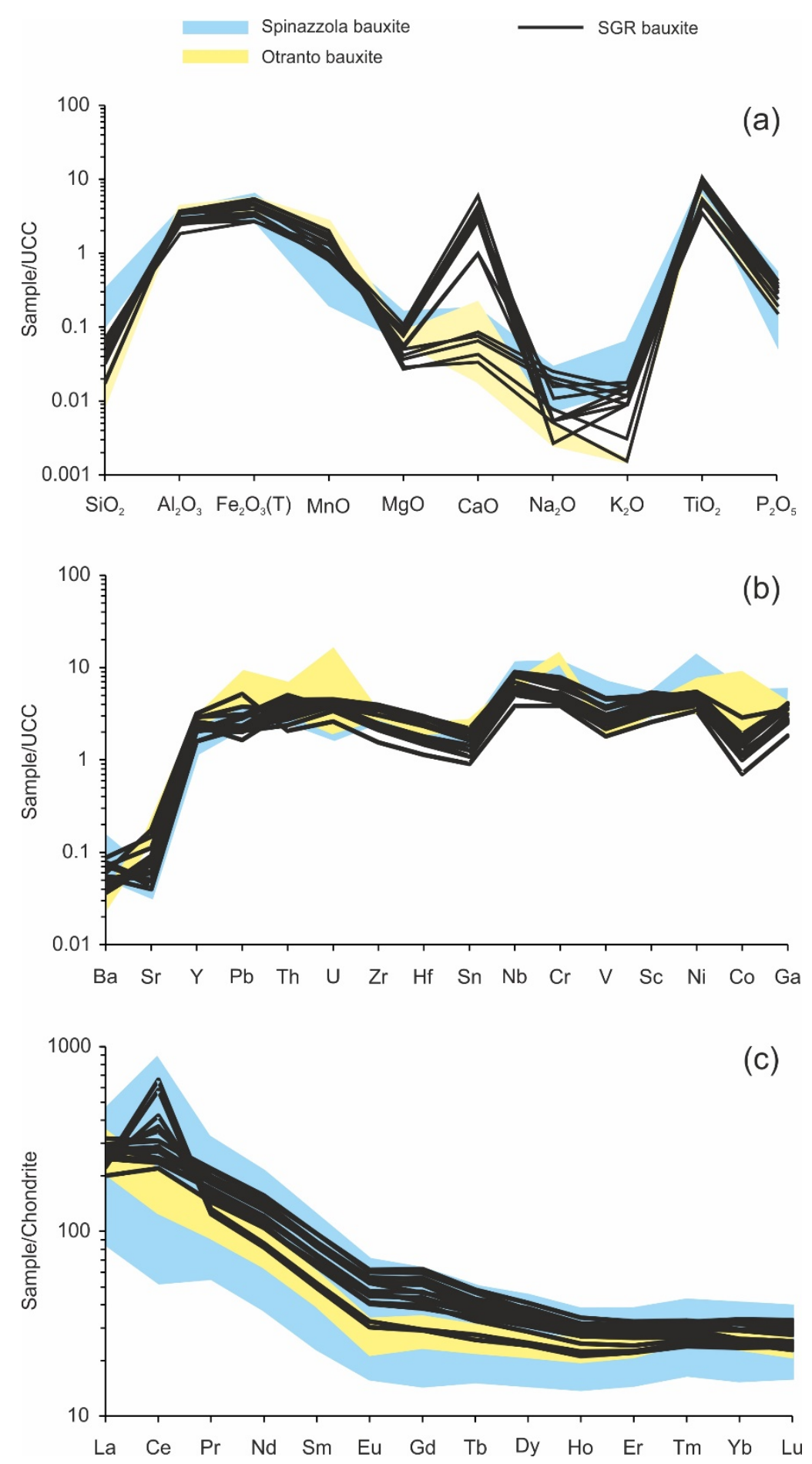

Figure 8. Major (a), trace (b), and rare earth elements (REEs), (c) normalization diagrams for the SGR samples. The compositional fields of bauxites from Spinazzola (Modified from Mongelli, et al. [16]) and Otranto (Modified from Mongelli, et al. [3]) are also displayed for comparison. See text for further details.

As for the trace elements (Figure 8b), the three Apulian deposits show LILE (Large Ione Lithophile Elements, mainly Ba and Sr) depletion, and HFSE (High Field Strength Elements, such as Zr, Hf, $\mathrm{Y}, \mathrm{Sn}, \mathrm{Nb}, \mathrm{Th}$, and $\mathrm{U}$ ) and transition metals (mainly $\mathrm{Cr}, \mathrm{V}, \mathrm{Sc}, \mathrm{Ni}, \mathrm{Co}$ ) enrichment, relative to the UCC's composition. Although their trace element distribution patterns are similar, the SGR deposit 
shows lower enrichments of $\mathrm{Pb}, \mathrm{U}, \mathrm{Cr}$, and Co relative to bauxite from Otranto and $\mathrm{Cr}$ and $\mathrm{Ni}$ from Spinazzola ore.

Finally, as displayed in Figure 8c, the SGR samples and the bauxite from Spinazzola and Otranto show similar paths of REEs distributions, although a wider range of total REEs concentrations and Ce anomaly values characterizes the Spinazzola deposit. However, regardless of the $\Sigma$ REE contents, significant REEs enrichments (up to 600X in the SGR samples, up to 800X in the Spinazzola deposit, and up to $350 \mathrm{X}$ in the bauxite from Otranto) relative to the Chondrite composition were found in all of the considered Apulian bauxites.

\section{Discussion}

Similarly to the bauxite from Spinazzola, the SGR deposit represents an accumulation of Al- and Fe-rich minerals formed by in situ sedimentary processes [24].

As suggested by Mongelli, [29], the formation of autochthonous bauxites includes three stages, in which clayey material deposition at the bottom of karst cavities, bauxitization (i.e., intense weathering), and late formation of ooidal concretions in a pedogenic environment occur. In such a natural environment, where dry and wet conditions alternate frequently, Fe- and Al-rich ooids may form and coexist [39]. Dry climate conditions promote the formation of boehmite, whereas wetter conditions favor the stability of Al-hematite [29,34]. As a consequence, the ooids observed in the SGR bauxite suggest that the bauxitization of pristine sediments occurred under alternating wet and dry conditions.

During bauxite formation, climate conditions also control the distribution of chemical elements between textural components [24]. In general, $\mathrm{SiO}_{2}$ is concentrated mostly in the clayey matrix, whereas $\mathrm{Al}_{2} \mathrm{O}_{3}, \mathrm{TiO}_{2}, \mathrm{Fe}_{2} \mathrm{O}_{3}$, and most trace metals are associated mainly with the ooids [14,16,29,33,34]. According to SEM observations and EDS microchemical analyses, this elemental distribution takes place in the SGR bauxite as well. As the chemical correlations suggest, in this deposit, the $\mathrm{Al}$ and Fe oxides and the oxihydroxide mineral phases exercise significant control over the distribution and mobility of most of the trace elements with the notable exception of Y and REEs, the presence of which seems to be due to the detrital component of the deposit. In fact, the negative correlation that exists between REEs and $\mathrm{CaO}$ also excludes the carbonate minerals in REEs retention processes.

During bauxitization, $\mathrm{pH}$ is the dominant controlling parameter for the mobility of REEs, causing the leaching of REEs in acidic conditions and their accumulation in alkaline conditions [40]. As a consequence, an enrichment of REEs in bauxite is indicative of the prevalence of alkaline conditions during its evolution [41]. Measuring variations in the La/Y ratio is a useful geochemical tool for determining changes in $\mathrm{pH}$ during bauxitization [42]. Values of La/Y $<1$ imply the prevalence of acidic conditions, whereas values of $\mathrm{La} / \mathrm{Y}>1$ indicate basic conditions. Throughout the SGR deposit, the La/Y ratio was found to have values above 1, suggesting that basic conditions constantly occurred during the SGR bauxite's formation, likely promoting the retention of REEs in the primary minerals as much as in the secondary mineral scavengers or authigenic phases. Several authors $[33,35,43-46]$ have suggested that authigenic REEs-bearing minerals are common in karst bauxites worldwide, and can be responsible for REEs enrichments in bauxite. Therefore, despite the lack of microscopic evidence, we cannot exclude the presence of these minerals in the SGR deposit. However, this is not relevant for the present study, because secondary and authigenic minerals are generally not used to obtain information about a bauxite deposit's source material.

The chemical composition of sedimentary rocks is an important record of the geological evolution of the continental crust through time because some elements are quantitatively transported in the terrigeneous fine fraction of a sediment [47]. However, the chemical composition of clastic sediments depends on several factors, including source-area composition, paleoweathering, sorting, and recycling $[48,49]$. Thus, in using a terrigenous sediment to retrieve provenance insights, one is faced with the nontrivial problem of evaluating and minimizing the effects of the other factors. Such a problem certainly arises during the study of bauxite deposits, as their formation is associated with intense chemical alteration of the source material that in some cases may hide or modify the 
provenance signatures. For this reason, much attention should be paid to trace elements when making provenance inferences.

For example, the abundance of $\mathrm{Cr}$ and $\mathrm{Ni}$ as well as their ratio $(\mathrm{Ni} / \mathrm{Cr})$ in siliciclastic sediments [50,51], and also in bauxites $[13,15,35]$, are considered to be useful indicators in provenance studies, and an Ni versus $\mathrm{Cr}$ binary plot is commonly used as a graphical support. In Figure 9, the distribution of the SGR samples in an $\mathrm{Ni}$ versus $\mathrm{Cr}$ diagram is displayed along with the compositional fields of the other Apulian karst bauxites.

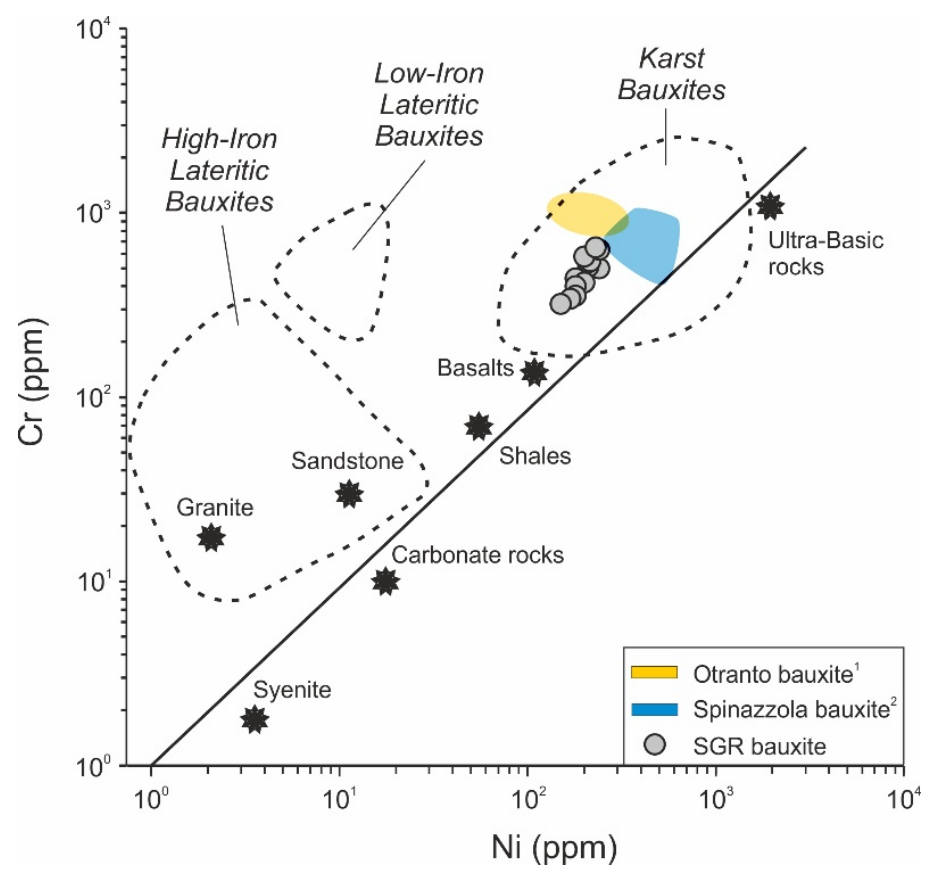

Figure 9. Ni versus Cr diagram showing the distribution of the SGR, Spinazzola, and Otranto karst bauxites. Modified after Schroll, et al. [52].

All three deposits fall within the field of karst bauxites, although each of them clusters in a well-defined area of the diagram. Such a distribution could be due to the geochemical behavior of $\mathrm{Ni}$ during weathering. It is well-known that, although the concentration of $\mathrm{Ni}$ within a bauxite may be affected by adsorption mechanisms that are associated with the presence of iron oxi-hydroxides, it is largely soluble as $\mathrm{Ni}^{2+}$ ions during intense weathering [53]. In addition, Buccione, et al. [54] demonstrated a significant relationship between the textural features of bauxite ores and their $\mathrm{Ni}$ contents, suggesting that $\mathrm{Ni}$ is preferentially retained in ores that are not affected by tectonic stress. Deformative events, in fact, can be responsible for enhanced fluid circulation that, in turn, induces greater Ni mobilization. This means that $\mathrm{Ni} / \mathrm{Cr}$ ratios do not necessarily reflect the protolith of the bauxite and need to be carefully interpreted.

In order to constrain the nature of a bauxite deposit's parent rocks, Torró, et al. [46] recently proposed the use of $\mathrm{Cr} / \mathrm{Zr}$, Ti $/ \mathrm{Cr}$, and $\mathrm{Zr} / \mathrm{TiO}_{2}$ ratios. However, because of the relatively high $\mathrm{TiO}_{2}$ contents of the studied bauxite ore, these ratios resulted in contrasting conclusions. The SGR bauxite, in fact, has low $\mathrm{Zr} / \mathrm{TiO}_{2}$ (average value $=0.01$ ) values, which are consistent with a mafic parent material, and high $\mathrm{Ti} / \mathrm{Cr}$ (average value $=47.6$ ) and low $\mathrm{Cr} / \mathrm{Zr}$ (average value $=0.85$ ) ratios that, conversely, point to felsic source rocks, thus proving that more reliable elements and elemental ratios must be used to assess the parental affinities of bauxite deposits.

It is generally accepted that, among trace elements, REEs are the most useful geochemical tools to assess the provenance of a sedimentary rock in general [47,55-57] and of a bauxite deposit in particular $[3,9,10,16]$. The REEs are thought to be conservative elements (i.e., elements relatively immobile during the weathering processes), because secondary processes do not affect 
their distribution as much as their elemental ratios [58-60]. Cerium, however, may fractionate with respect to the other rare earth elements because its geochemical behavior during weathering may be strongly affected by changes in redox state. Consequently, the weathered material can be enriched or depleted in $\mathrm{Ce}$, and accordingly shows positive or negative Ce anomalies. Several authors [33,61] have demonstrated that positive $\mathrm{Ce}$ anomalies in lateritic profiles and bauxites are mineralogically related to the precipitation of cerianite $\left(\mathrm{CeO}_{2}\right)$ due to the $\mathrm{Ce}^{3+}$ to $\mathrm{Ce}^{4+}$ redox change. Such a process is likely to be responsible for the positive Ce anomalies observed throughout the SGR deposit and indicates that oxidizing conditions persisted during the bauxitization process.

The REE pattern and some elemental ratios, especially $\mathrm{Eu} / \mathrm{Eu}^{*}$ and $(\mathrm{La} / \mathrm{Yb})_{\mathrm{N}}$, mirror the exposed crustal abundances in the source area [55,58,62-64]. As was previously shown (Figure 8c), the chondrite-normalized REE patterns of SGR samples have paths typical of Apulian autochthonous karst bauxites and of sediments derived from the upper continental crust, with LREE and HREE fractionation indices values (the mean $(\mathrm{La} / \mathrm{Yb})_{\mathrm{N}}$ value for SGR samples $=9.3$ ) comparable to that of PAAS (Post-Archean Australian Shale, [47]) and UCC $\left((\mathrm{La} / \mathrm{Yb})_{\mathrm{N}}=9.2\right)$. According to Mongelli, et al. [24], the REE distribution patterns of the Otranto ore slightly differ from those of the other Apulian deposits likely because of its allochthonous nature.

The Eu anomaly is an index of chemical differentiation, and, more often than other provenance proxies, reflects the proportion of exposed crust in the source area(s) $[58,59,63,65]$ during bauxitization $[10,13]$. Negative $\mathrm{Eu} / \mathrm{Eu}^{*}$ anomalies are a geochemical feature of post-Archean cratonic sediments [66] and are usually associated with mafic source rocks. As was previously stated, in the SGR bauxite the $\mathrm{Eu} / \mathrm{Eu}^{*}$ values were uniform, signifying that bauxitisation has not affected the $\mathrm{Eu}$ anomaly values within the study area. The SGR bauxite has Eu anomalies that are significantly higher $\left(0.79<\mathrm{Eu} / \mathrm{Eu}^{*}<0.85\right)$ than the Eu anomaly of the upper continental crust standards $\left(\mathrm{Eu} / \mathrm{Eu}^{*} \mathrm{PAAS}=0.61, \mathrm{Eu} / \mathrm{Eu}^{*} \mathrm{UCC}=0.66\right)$, meaning that the studied bauxite has a more "mafic" geochemical signature.

In this study, the relationships between the Eu anomaly and the $\mathrm{Sm} / \mathrm{Nd}$ ratio were also used to determine parental affinities for the SGR karst bauxite. Similarly to Eu anomalies, the Sm/Nd ratio is an index of chemical differentiation, since only a minor fractionation of $\mathrm{Sm}$ and $\mathrm{Nd}$ occurs during intense tropical weathering [67].

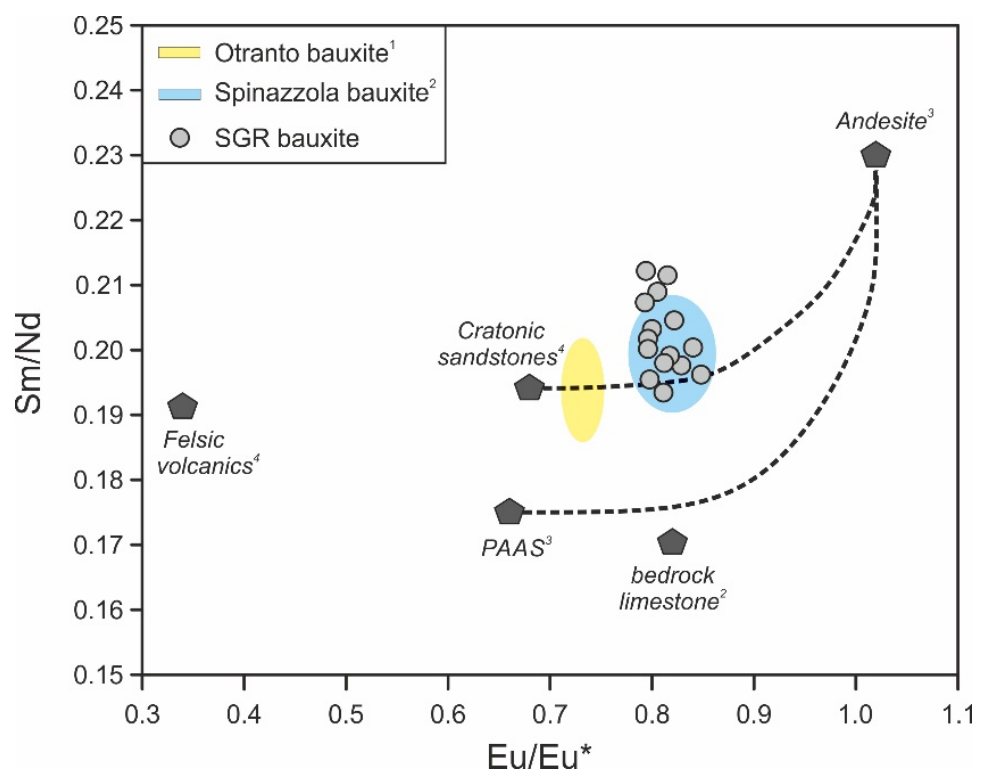

Figure 10. Eu/ $\mathrm{Eu}^{*}$ versus $\mathrm{Sm} / \mathrm{Nd}$ diagram showing mixing lines between average standard lithologies. Grey circles are samples from the SGR bauxite; yellow and blue ovals are the compositional fields of the Otranto and Spinazzola bauxites, respectively. 1: data from [14], 2: data from [13], 3: data from [35], 4: data from [51]. 
Figure 10 displays the distribution of the studied samples, the other Apulian karst bauxites, and the average standard lithologies representative of siliciclastic sediments (cratonic sandstones and PAAS), volcanic rocks (felsic and basaltic andesites), and early Cretaceous limestone from the ACP (bedrock limestone) Within the binary $\mathrm{Eu} / \mathrm{Eu}^{*}$ versus $\mathrm{Sm} / \mathrm{Nd}$ diagram. The SGR samples plot close a mixing curve that links the cratonic sandstones and basaltic andesites' end-members, along which the samples of bauxites from Spinazzola and Otranto are also distributed. Specifically, the samples here examined overlap those of the Spinazzola bauxite, suggesting a strong compositional affinity between the two autochthonous deposits. Consequently, a common provenance for the Spinazzola and SGR deposits may be supposed. According to Mongelli, et al. [16], therefore, the SGR karst bauxite can be thought of as a mixture of windborne magmatic material, likely deriving from a distant volcanic source (such as the subduction-related magmatism of the Dinaric and Carpatho-Balkan Orogenic Belts active during the late Cretaceous period [15]), and dominant clastic material that is derived from a close continental margin (the North Africa craton?).

\section{Conclusions}

Bauxitization is a complex weathering process that involves intense chemical alteration of the source rock and/or sediments. Such a process commonly causes mineral transformations and chemical changes that may hide the provenance signatures. To avoid mistakes in provenance determinations, the use of conservative elements, such as rare earth elements, is recommended. Distribution patterns of chondrite-normalized REE concentrations, along with LREE to HREE fractionation indices, show that the SGR deposit has REE paths typical of siliciclastic sediments, with $(\mathrm{La} / \mathrm{Yb})_{\mathrm{N}}$ ratios comparable to those of PAAS and UCC. La/Y values constantly above 1, positive Ce anomalies, and negative $\mathrm{Eu}$ anomalies are present throughout the SGR deposit, suggesting that (1) it formed under relatively stable basic (high $\mathrm{pH}$ ) and oxidizing (high Eh) conditions, and (2) the bauxite's parental material has an evident mafic component. This is also supported by the $\mathrm{Eu} / \mathrm{Eu}^{*}$ versus $\mathrm{Sm} / \mathrm{Nd}$ plot, in which the SGR samples were distributed along the andesite-cratonic sandstone mixing curve.

Based on the presented data, it is also supposed that the SGR bauxite deposit shares its source material with the other autochthonous bauxites of the Apulia region, which consist of a combination of magmatic (distant windborne volcanic particles) and siliciclastic (of cratonic origin) material. As a result, a direct connection between the ACP and the African promontory seems to be possible, supporting the inferences that were previously disclosed by Mongelli, et al. [16].

Funding: This research was economically supported by a Giovanni Mongelli grant [RIL2016].

Acknowledgments: Author wishes to thank Giovanni Mongelli for the critical reading of the manuscript and his incomparable support during the paper drafting. Many thanks also to R. Buccione for his support during fieldwork and sampling, and to the Editor and two anonymous reviewers whose comments and suggestions improved the final version of the manuscript.

Conflicts of Interest: The authors declare no conflict of interest.

\section{References}

1. Bárdossy, G.; Aleva, G.J.J. Lateritic Bauxites; Elsevier: Amsterdam, The Netherlands, 1990; p. 624.

2. Herrington, R. Road map to mineral supply. Nat. Geosci. 2013, 6, 892-894. [CrossRef]

3. Mongelli, G.; Buccione, R.; Gueguen, E.; Langone, A.; Sinisi, R. Geochemistry of the Apulian allochthonous karst bauxite, Southern Italy: Distribution of critical elements and constraints on Late Cretaceous Peri-Tethyan palaeogeography. Ore Geol. Rev. 2016, 77, 246-259. [CrossRef]

4. Mongelli, G.; Boni, M.; Oggiano, G.; Mameli, P.; Sinisi, R.; Buccione, R.; Mondillo, N. Critical metals distribution in Tethyan karst bauxite: The Cretaceous Italian ores. Ore Geol. Rev. 2017, 86, 526-536. [CrossRef]

5. Bárdossy, G. Karst Bauxites, Bauxite Deposits on Carbonate Rocks. Developments in Economic Geology 14; Elsevier: Amsterdam, The Netherlands, 1982; p. 441.

6. D'Argenio, B.; Mindszenty, A. Bauxites and related paleokarst: Tectonic and climatic event markers at regional unconformity. Eclogae Geol. Helv. 1995, 88, 453-499. 
7. Öztürk, H.; Hein, J. Genesis of the Doğnkuzu and Mortaş Bauxite Deposits, Taurides, Turkey: Separation of $\mathrm{Al}, \mathrm{Fe}$, and $\mathrm{Mn}$ and implications for passive margin metallogeny. Econ. Geol. 2002, 97, 1063-1077. [CrossRef]

8. Laskou, M. Geochemical and mineralogical characteristics of the bauxite deposits of Western Greece. Miner. Explor. Sustain. Dev. 2003, 77, 93-96.

9. Calagari, A.A.; Abedini, A. Geochemical investigations on Permo-Triassic bauxite deposit at Kanisheeteh, east of Bukan, Iran. J. Geochem. Explor. 2007, 94, 1-18. [CrossRef]

10. Mameli, P.; Mongelli, G.; Oggiano, G.; Dinelli, E. Geological, geochemical and mineralogical features of some bauxite deposits from Nurra (western Sardinia, Italy): Insights on conditions of formation and parental affinity. Int. J. Earth Sci. 2007, 96, 887-902. [CrossRef]

11. Liu, X.; Wang, Q.; Deng, J.; Zhang, Q.; Sun, S.; Meng, J. Mineralogical and geochemical investigations of the Dajia Salento-type bauxite deposits, Western Guangxi, China. J. Geochem. Explor. 2010, 105, 137-152. [CrossRef]

12. Yuste, A.; Bauluz, B.; Mayayo, M.J. Origin and geochemical evolution from ferrallitized clays to karst bauxite: An example from the Lower Cretaceous of NE Spain. Ore Geol. Rev. 2017, 84, 67-79. [CrossRef]

13. Mondillo, N.; Boni, M.; Balassone, G.; Rollinson, G. Karst bauxites in the Campania Apennines (southern Italy): A new approach. Period. Mineral. 2011, 80, 407-432.

14. Boni, M.; Rollinson, G.; Mondillo, N.; Balassone, G.; Santoro, L. Quantitative mineralogical characterization of karst bauxite deposits in the Southern Apennines, Italy. Econ. Geol. 2013, 108, 813-833. [CrossRef]

15. Boni, M.; Reddy, S.M.; Mondillo, N.; Balassone, G.; Taylor, R. A distant magmatic source for Cretaceous karst bauxites of southern Apennines (Italy), revealed through SHRIMP zircon age dating. Terra Nova 2012, 24, 326-332. [CrossRef]

16. Mongelli, G.; Boni, M.; Buccione, R.; Sinisi, R. Geochemistry of the Apulian karst bauxites (southern Italy). Chemical fractionation and parental affinities. Ore Geol. Rev. 2014, 63, 9-21. [CrossRef]

17. Stampfli, G.M. Tectonics and Magmatism in Turkey and the Surrounding Area. Geol. Soc. Lond. Spec. Publ. 2000, 173, 1-23. [CrossRef]

18. Ricchetti, G.; Ciaranfi, N.; Luperto Sinni, E.; Mongelli, F.; Pieri, P. Geodinamica ed evoluzione sedimentaria e tettonica dell'avanpaese apulo. Mem. Soc. Geol. Ital. 1992, 41, 57-82.

19. Mindszenty, A.; D'Argenio, B.; Aiello, G. Lithospheric bulges at regional unconformities. The case of Mesozoic-Tertiary in Apulia. Tectonophysics 1995, 252, 137-161. [CrossRef]

20. Funiciello, R.; Montone, P.; Parotto, M.; Salvini, F.; Tozzi, M. Geodynamical evolution of an intra-orogenic foreland: The Apulia case history (Italy). Boll. Soc. Geol. Ital. 1991, 110, 419-425.

21. Bosellini, A.; Neri, C.; Luciani, V. Platform margin collapses and sequence stratigraphic organization of carbonate slopes: Cretaceous-Eocene, Gargano Promontory, southern Italy. Terra Nova 1993, 5, 282-297. [CrossRef]

22. Graziano, R. The Aptian-Albian of the Apulia Carbonate Platform (Gargano Promontory, southern Italy): Evidence of palaeoceanographic and tectonic controls on the stratigraphic architecture of the platform margin. Cretac. Res. 2000, 21, 107-126. [CrossRef]

23. Esu, D.; Girotti, O. The late Oligocene molluscan fauna from Otranto (Apulia, Southern Italy): An example of alternating freshwater, lagoonal and emerged environments. Palaeontology 2010, 53, 137-174. [CrossRef]

24. Mongelli, G.; Buccione, R.; Sinisi, R. Genesis of autochthonous and allochthonous Apulian karst bauxites (Southern Italy): Climate constraints. Sediment. Geol. 2015, 325, 168-176. [CrossRef]

25. Claps, M.; Parente, M.; Neri, C.; Bosellini, A. Facies and Cycles of the S. Giovanni Rotondo Limestone (Lower Cretaceous, Gargano Promontory, Southern Italy): The Borgo Celano Section; Universita di Ferrara, Dipartimento di Scienze della Terra: Ferrara, Italy, 1996; Volume 7, pp. 1-35.

26. Luperto Sinni, E. Sintesi delle conoscenze biostratigrafiche del Cretaceo del Gargano e delle Murge. Mem. Soc. Geol. Ital. 1996, 51, 995-1018.

27. Bosellini, A.; Morsilli, M.; Neri, C. Longterm event stratigraphy of the Apulia Platform margin (Upper Jurassic to Eocene, Gargano, Southern Italy). J. Sediment. Res. 1999, 69, 1241-1252. [CrossRef]

28. Spalluto, L.; Pieri, P.; Ricchetti, G. Inner platform carbonate facies of the Gargano Promontory: Implications for paleoenviroments and correlation with the coeval succession of the Murge area (Southern Italy, Puglia). Boll. Soc. Geol. Ital. 2005, 124, 675-690.

29. Mongelli, G. Growth of hematite and boehmite in concretions from ancient karst bauxite: Clue for past climate. Catena 2002, 50, 43-51. [CrossRef]

30. Morsilli, M. Sintesi delle Conoscenze Geologiche e Stratigrafiche del Promontorio del Gargano; Ordine Regionale dei Geologi Puglia: Bari, Italy, 2016; Volume 2, pp. 15-30. 
31. Evensen, M.N.; Hamilton, P.J.; O'Nions, R.K. Rare earth abundances in chondritic meteorites. Geochim. Cosmochim. Acta 1978, 42, 1199-1212. [CrossRef]

32. Worrall, F.; Pearson, D.G. Water-rock interaction in an acidic mine discharge as indicated by rare earth element patterns. Geochim. Cosmochim. Acta 2001, 65, 3027-3040. [CrossRef]

33. Mongelli, G. Ce-anomalies in the textural components of Upper Cretaceous karst bauxites from the Apulian Carbonate Platform (Southern Italy). Chem. Geol. 1997, 140, 69-79. [CrossRef]

34. Mongelli, G.; Acquafredda, P. Ferruginous concretions in a Late Cretaceous karst bauxite: Composition and conditions of formation. Chem. Geol. 1999, 158, 315-320. [CrossRef]

35. Putzolu, F.; Papa, A.P.; Mondillo, N.; Boni, M.; Balassone, G.; Mormone, A. Geochemical characterization of bauxite deposits from the abruzzi mining district (Italy). Minerals 2018, 8, 298. [CrossRef]

36. Gu, J.; Huang, Z.; Fan, H.; Jin, Z.; Yan, Z.; Zhang, J. Mineralogy, geochemistry, and genesis of lateritic bauxite deposits in the Wuchuan-Zheng'an-Daozhenarea, Northern Guizhou Province, China. J. Geochem. Explor. 2013, 130, 44-59. [CrossRef]

37. Zamaniana, H.; Ahmadnejad, F.; Zarasvandi, A. Mineralogical and geochemical investigations of the Mombi bauxitedeposit, Zagros Mountains, Iran. Chem. Erde-Geochem. 2016, 76, 13-37. [CrossRef]

38. McLennan, S.M.; Taylor, S.R.; Hemming, S.R. Composition, differentiation, and evolution of continental crust: Constrains from sedimentary rocks and heat flow. In Evolution and Differentiation of the Continental Crust; Brown, M., Rushmer, T., Eds.; Cambridge University Press: Cambridge, UK, 2006; pp. 92-134.

39. Paquet, H.; Clauer, N. Soils and Sediments. Mineralogy and Geochemistry; Springer: Berlin, Germany, 1997.

40. Fleet, A.J. Aqueous and sedimentary geochemistry of the rare earth elements. In Rare Earth Element Geochemistry; Henderson, P., Ed.; Elsevier: Amsterdam, The Netherlands, 1984; pp. 343-373.

41. Abedini, A.; Calagari, A.A. Geochemical characteristics of Kanigorgeh ferruginous bauxite horizon, West-Azarbaidjan province, NW Iran. Period. Mineral. 2013, 82, 1-23.

42. Ellahi, S.S.; Taghipour, B.; Zarasvandi, A.; Bird, M.I.; Somarin, A.K. Mineralogy, geochemistry and stable isotope. studies of the dopolan bauxite deposit, Zagros Mountain, Iran. Minerals 2016, 6, 11. [CrossRef]

43. Wang, Q.; Deng, J.; Liu, X.; Zhang, Q.; Sun, S.; Jiang, C.; Zhou, F. Discovery of the REE minerals and its geological significance in the Quyang bauxite deposit, West Guangxi, China. J. Asian Earth Sci. 2010, 39, 701-712. [CrossRef]

44. Liu, X.; Wang, Q.; Zhang, Q.; Zhang, Y.; Li, Y. Genesis of REE minerals in the karstic bauxite in Western Guangxi, China, and its constraints on the deposit formation conditions. Ore Geol. Rev. 2016, 75, 100-115. [CrossRef]

45. Proenza, J.; Aiglsperger, T.; Villanova-de-Benavent, C.; Torró, L.; Rodríguez-García, D.; Rodríguez, J. Discovery of REE minerals hosted in karst bauxite ores from the Sierra de Bahoruco, Pedernales, Dominican Republic. In Proceedings of the 14th SGA Biennial Meeting: Mineral Resources to Discover, Québec City, QC, Canada, 20-23 August 2017; Voluem 4, pp. 1321-1324.

46. Torró, L.; Proenza, J.A.; Aiglsperger, T.; Bover-Arnal, T.; Villanova-de-Benavent, C.; Rodríguez-Garcia, D.; Ramírez, A.; Rodríguez, J.; Mosquea, L.A.; Salas, R. Geological, Geochemical and mineralogical characteristics of REE-bearing Las Mercedes bauxite deposit, Dominican Republic. Ore Geol. Rev. 2017, 89, 114-131. [CrossRef]

47. Taylor, S.R.; McLennan, S.M. The Continental Crust: Its Composition and Evolution; Blackwell: Oxford, UK, 1985; pp. 1-312.

48. Mongelli, G.; Critelli, S.; Perri, F.; Sonnino, M.; Perrone, V. Sedimentary recycling, provenance and paleoweathering from chemistry and mineralogy of Mesozoic continental redbed mudrocks, Peloritani Mountains, Southern Italy. Geochem. J. 2006, 40, 197-209. [CrossRef]

49. Perri, F.; Critelli, S.; Mongelli, G.; Cullers, R.L. Sedimentary evolution of the Mesozoic continental redbeds using geochemical and mineralogical tools: The case of Upper Triassic to Lowermost Jurassic Monte di Gioiosa mudrocks (Sicily, southern Italy). Int. J. Earth Sci. 2010, 100, 1569-1587. [CrossRef]

50. Wrafter, J.P.; Graham, J.R. Ophiolitic detritus in the Ordovician sediments of South Mayo Ireland. J. Geol. Soc. 1989, 146, 213-215. [CrossRef]

51. Armstrong-Altrin, J.S.; Lee, Y.I.; Verma, S.P.; Ramasamy, S. Geochemistry of sandstones from the upper Miocene Kudankulam formation, southern India: Implications for provenance, weathering, and tectonic setting. J. Sediment. Res. 2004, 74, 285-297. [CrossRef]

52. Schroll, E.; Sauer, D. Beitrag zur Geochemie von Titan, Chrom, Nikel, Cobalt, Vanadium und Molibdan in Bauxitischen gestermenund problem der stofflichen herkunft des Aluminiums. Travaux ICSOBA 1968, 5, 83-96. 
53. Gaillardet, J.; Viers, J.; Dupre, B. Trace elements in river waters. In Treatise of Geochemistry; Drever, J.I., Ed.; Elsevier-Pergamon: Oxford, UK, 2003; pp. 225-272.

54. Buccione, R.; Mongelli, G.; Sinisi, R.; Boni, M. Relationship between geometric parameters and compositional data: A new approach to karst bauxites exploration. J. Geochem. Explor. 2016, 169, 192-201. [CrossRef]

55. Fedo, C.M.; Eriksson, K.A.; Krogstad, E.J. Geochemistry of shales from the Archean (3.0 Ga) Buhwa Greenstone belt, Zimbabwe: Implication for provenance and source area weathering. Geochim. Cosmochim. Acta 1996, 60, 1751-1763. [CrossRef]

56. Plank, T.; Langmuir, C.H. The chemical composition of subducting sediment and its composition for the crust and mantle. Chem. Geol. 1998, 145, 325-394. [CrossRef]

57. McLennan, S.M. Relationships between the Trace Element Composition of Sedimentary Rocks and Upper Continental Crust. Geochem. Geophys. Geosyst. 2001, 2. [CrossRef]

58. McLennan, S.M.; Hemming, D.K.; Hanson, G.N. Geochimical approaches to sedimentation, provenance and tectonics. Geol. Soc. Am. Spec. Pap. 1993, 284, 21-40.

59. Cullers, R.L. The geochemistry of shales, siltstones and sandstones of Pennsylvian-Permian age, Colorado, USA: Implications for provenance and metamorphic studies. Lithos 2000, 51, 181-203. [CrossRef]

60. Corcoran, P.L. Recycling and chemical weathering in tectonically controlled Mesozoic-Cenozoic basins of New Zealand. Sedimentology 2005, 52, 757-774. [CrossRef]

61. Braun, J.J.; Pagel, M.; Muller, J.P.; Bilong, P.; Michard, A.; Guillet, B. Cerium anomalies in lateritic profiles. Geochim. Cosmochim. Acta 1990, 54, 781-795. [CrossRef]

62. Hassan, S.; Ishiga, H.; Roser, B.P.; Dozen, K.; Naka, T. Geochemistry of Permian Triassic shales in the Salt range, Pakistan: Implications for provenance and tectonism at the Gondwana margin. Chem. Geol. 1999, 168, 293-314. [CrossRef]

63. Condie, K.C.; Lee, D.; Farmer, G.L. Tectonic setting and provenance of the Neoproterozoic Uinta Mountain and Big Vottonwood groups, northern Utah: Constraints from geochemistry, Nd isotopes, and detrital modes. Sediment. Geol. 2001, 141, 43-464.

64. Mongelli, G. Rare-earth elements in Oligo-Miocenic politic sediments from Lagonegro basin, southern Apennines, Italy: Implications for provenance and source-area weathering. Int. J. Earth Sci. 2004, 93, 612-620.

65. Sinisi, R.; Mongelli, G.; Mameli, P.; Oggiano, G. Did the Variscan relief influence the Permian climate of Mesoeurope? Insights from geochemical and mineralogical proxies from Sardinia (Italy). Palaeogeogr. Palaeoclimatol. Palaeoecol. 2014, 396, 132-154. [CrossRef]

66. Rudnick, R.L. Restites, Eu anomalies, and the lower continental crust. Geochim. Cosmochim. Acta 1992, 56, 963-970. [CrossRef]

67. Viers, J.; Wasserburg, G.J. Behavior of Sm and Nd in a lateritic soil profile. Geochim. Cosmochim. Acta 2004, 68, 2043-2054. [CrossRef]

(c) 2018 by the author. Licensee MDPI, Basel, Switzerland. This article is an open access article distributed under the terms and conditions of the Creative Commons Attribution (CC BY) license (http://creativecommons.org/licenses/by/4.0/). 